\title{
MOSTAR AIRPORT STRATEGIC DEVELOPMENT MODEL
}

\author{
Andrija Vidović, Tomislav Mihetec, Daniel Galić
}

Subject review

Since 2010, the Mostar Airport has had significant traffic results after 10 year long post-war traffic stagnation. In recent years a number of passengers doubled, while the traffic numbers at the end of 2012 reached the figures before the war. In order to be able to meet traffic demand and actively face the challenges that lie ahead, and to train professionals properly, the Mostar Airport should develop specific planning documents that should serve as guidelines for future coordinated, planned and sustainable development. This development should be planned in regard to customers, passengers and airline satisfaction. This paper presents the research for the Mostar Airport, for which mid-term traffic forecast and strategic development model was developed. Strategic development model could be applied on all airports in Bosnia and Herzegovina (under the conditions that all airports have previously created master plan), with some adjustments.

Keywords: air traffic; Mostar Airport; strategic planning; traffic forecast

\section{Strateški model razvoja Zračne luke Mostar}

Pregledni članak

Zračna luka Mostar, nakon poslijeratne stagnacije prometa duge više od 10 godina, od 2010. godine ponovo počinje bilježiti značajnije prometne rezultate. Zadnjih godina broj putnika se udvostručavao te je krajem 2012. godine dosegao predratne brojke. Kako bi bila u mogućnosti zadovoljiti prometnu potražnju te se aktivno suočiti sa izazovima koji joj predstoje, pored adekvatno osposobljenih stručnjaka mora razviti i određenu plansku dokumentaciju koja će biti putokaz budućeg koordiniranog, planskog i održivog razvoja, a na zadovoljstvo korisnika usluga odnosno putnika i zračnih prijevoznika te ostalih subjekata izravno ili neizravno vezanih uz rad zračne luke.U ovom radu je izrađena srednjoročna prognoza prometa za Zračnu luku Mostar te je predstavljen model strateškog razvoja zračne luke koji bi uz određene prilagodbe bio primjenjiv na sve zračne luke u Bosni i Hercegovini uz preduvjet da zračne luke imaju prethodno izrađen Master plan.

Ključne riječi: prognoza prometa; strateško planiranje; Zračna luka Mostar; avionski promet

\section{Introduction}

Mostar Airport is reconstructed from military airport, and is operational from 1965 for civil air traffic. Until the dissolution of Yugoslavia, the Mostar Airport had up to 100000 passengers per year. The war stopped the traffic growth, and the post-war passenger number decreased to about 10000 passengers per year.

In 2010 passenger traffic sharply increased to 18000 , in 2011 to 37000 , and in 2012 to 78000 passengers. Passenger traffic data for 2013 and 2014 suddenly fell, but for 2015 it is expected to be about $10 \%$ higher compared to previous years.

Mostar Airport should develop master plan according to the principles defined by the International Civil Aviation Organisation (ICAO). Great number of challenges that occur in the development of the master plan leaves open the question of realization. Therefore, a new approach was applied to develop airport plans. They are so-called strategic development plans. Strategic development plan is used for commercialization of the airport services and contains dynamic elements that focus more on economic, marketing, financial and other changes. Airport Strategic Planning (ASP) focuses on the development of plans for the long-term development of an airport. The dominant approach for ASP is Airport Master Planning (AMP).The goal of AMP is to provide a detailed blueprint for how the airport should look in the future, and how it can get there [1].

\section{The social and economic impact of airports}

In air transport, the evolution of traffic depends upon many economic factors, and on the way in which the markets participants respond to those factors. Although airlines are the main actors, the airports are by no means passive, and their strategies will also have an impact on airline behaviour and route development [2].

Basically there are two types of economic impacts of airports [3]. In the first place there is income, employment, capital investment and airport taxes. Secondly, there is a wider catalytic or so called "spin off" impact of airports on the economy, which is reflected in the internal investment and tourism development (Fig. 1).

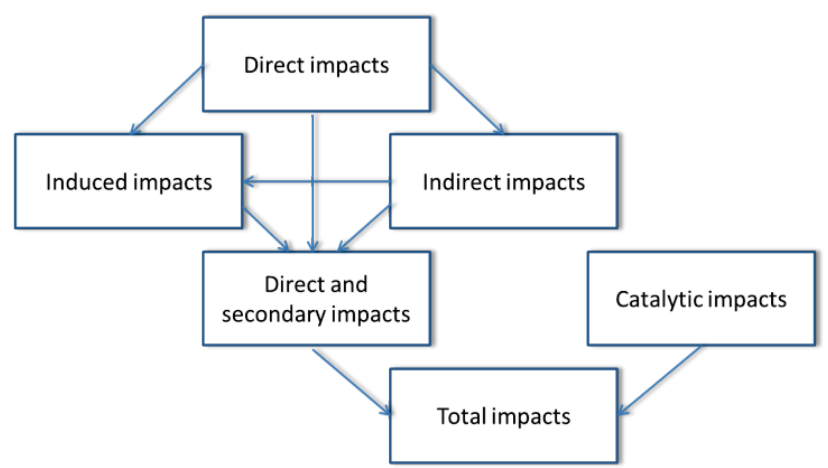

Figure 1 The economic impact of airports [3]

Services provided by airlines, airports, aircraft maintenance, air traffic control, and service industries such as the ground handling, shops and restaurants are considered as a generator of employment and economic activity of air transport system. Activities of aviation equipment manufacturers, sales of aircraft and its components, aircraft maintenance and related businesses also have direct impact on air transport system. Air transport system generates more than 8,7 million direct jobs in the world [4]. 
An indirect impact of air traffic includes jobs and careers that are provided by suppliers of secondary services included in air traffic (e.g. fuel suppliers, construction companies that build facilities at airports, manufacturers of goods that are sold at airports and a wide range of activities in the sector of business services such as call centres, IT services, accounting, etc.). Almost 10 million jobs are generated by companies that fully or partly provide goods or services to the airline industry [4].

Induced impact of air traffic involves spending expenditures of those who are directly or indirectly employed in the aviation sector, thus supporting jobs in other industries, such as companies producing consumer goods, an array of different services, etc.

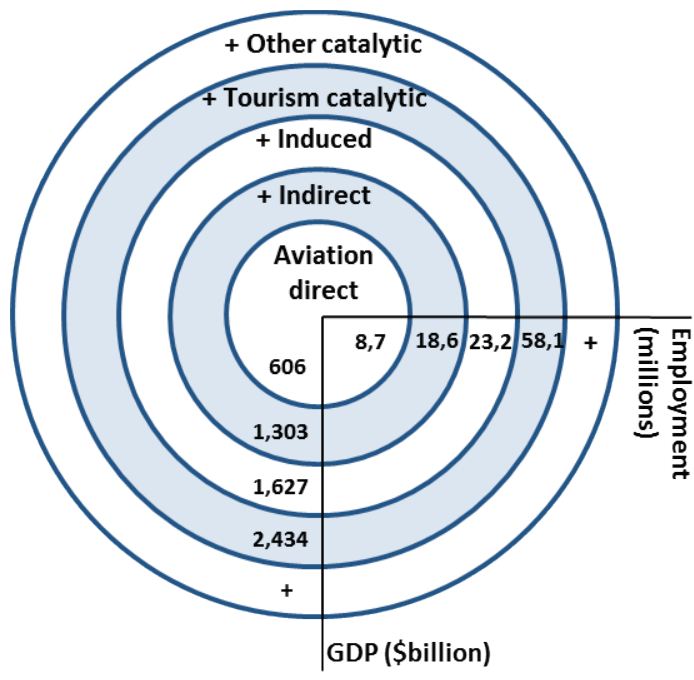

Figure 2 Global economic impact - employment and GDP [4]

4,6million jobs are supported through induced effects of employees in the air traffic system, which use their income to purchase goods and services for personal consumption. Induced contribution of air traffic in the world's GDP in 2012 was estimated at 324 million USD. Aviation's global economic impact including direct, indirect, induced and tourism catalytic was estimated at 2.424 billion USD in 2012 (Fig. 2) [4].

\section{Traffic forecast for the Mostar Airport}

Međugorje is the worlds' famous and one of the most visited pilgrimage sites in the world, in the field of religious tourism. Its distance from Mostar is only $25 \mathrm{~km}$. The exact number of pilgrims is not known, because there is no statistical monitoring of tourist development in this region. It is assumed that between 1981 and 2011 Međugorje was visited by more than 30 million pilgrims [5].

Airports that pilgrims use for their visit to Međugorje are mainly the airports in Croatia - Dubrovnik and the Split airport. Also in a much smaller number, pilgrims use airports in the Federation of Bosnia and Herzegovina Sarajevo and the Mostar Airports.

In order to estimate the potential number of passengers for the Mostar Airport, we rounded the average number of tourists who visit Međugorje to one million annually.

It is estimated that of the total number of tourists in Međugorje, $80 \%$ are foreigners, and $30 \%$ of them visited Međugorje using air transport services. The Mostar
Airport serves only $8 \%$ of the total estimated number of tourists that use services of air transport, which means that $92 \%$ of the passenger traffic is dispersed to the Dubrovnik, Split and Sarajevo airport.

The Mostar Airport management, together with the City of Mostar, tourist offices (city and county) and higher levels of government must recognize the potential, and with an active approach try to mitigate unfavourable current situation.

Fig. 3 presents the maximum potential number of passengers for the Mostar Airport based on the number of tourists visiting Međugorje. This model is based on the optimistic scenario with the assumption of high forecast of tourist arrivals to Međugorje. It should take into account a lack of precise statistical data concerning the tourist arrivals to Međugorje from the official statistical office of Bosnia and Herzegovina and that the only relevant data used in this model was obtained by the Catholic Church. For the airport statistics, inbound and outbound passengers are always counted separately which means that total number of passenger traffic at airports especially in charter traffic, for the purpose of traffic planning, is multiplied by 2 (one passenger enplaning and one deplaning).

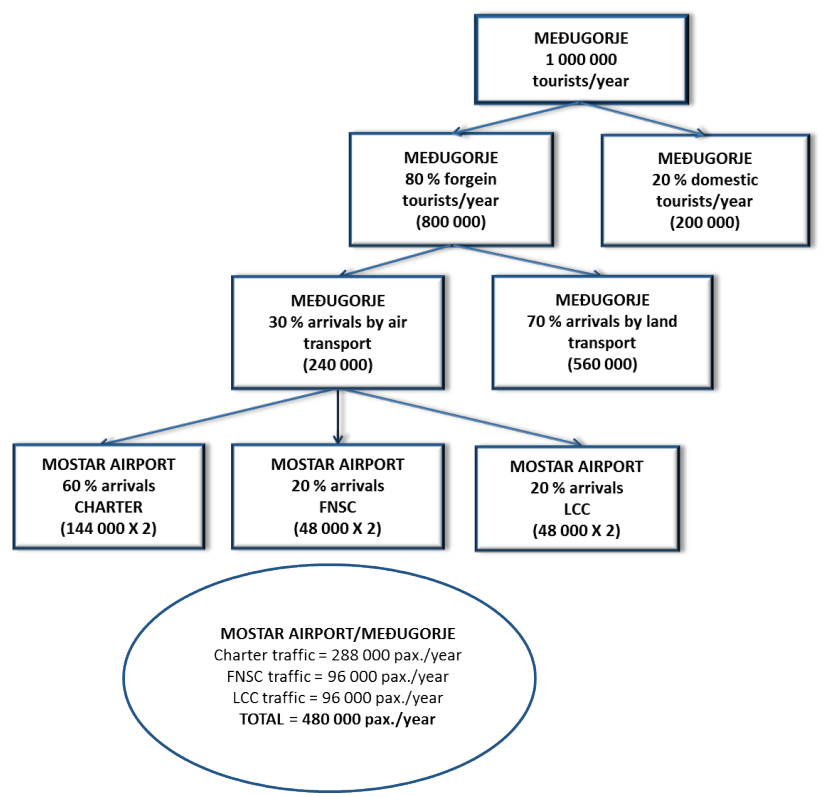

Figure 3 Estimation model of maximum potential tourist arrivals for the Mostar Airport catchment area [5]

Due to the above mentioned it is not realistic to achieve the optimistic traffic numbers in Fig. 3. The relevant numbers from the realistic forecast are described later in this paper.

As for the segment of regional air transport, it is important to emphasize that Herzegovina is a geographically small area with about 450000 inhabitants. The Mostar Airport is located in the middle of the region and is easily accessible by all residents of the region (up to an hour by car). Given the location, the airport is easily accessible to the residents of southern Dalmatia who live in the area from Split to Dubrovnik and to the residents of parts of Bosnia. Therefore, it is estimated that in the gravitational field of the Mostar Airport there is about 500000 residents that can reach the Mostar Airport by car in an hour and a half. 
According to the contemporary literature which is based on statistical and experience models, when planning the potential number of passengers from the catchment area of the airport, up to 6 to $9 \%$ of the total population depending on the development of the country is used to forecast the potential number of passengers from the catchment area [6].

With the fact that Bosnia and Herzegovina is a country with a low gross domestic product and the population has low purchasing power, in order to plan the potential traffic from the catchment area of the Mostar Airport, number of users of air transport services shall be based on the estimate of $7 \%$, which is 35000 of potential users of air transport services. This estimation of $7 \%$ is based on the assumption that South-East European area is opening to the new market conditions (South-East European countries are participating in the pre-accession negotiations with the EU). It can be assumed that $75 \%$ of passengers shall be using air transport in both directions, and with that assumption we come to the total number of 61250 users of the Mostar Airport. If to this number we add diverted flights from Sarajevo during the winter months, when due to bad weather the Sarajevo airport is temporarily closed, we can count with an increase of additional 10000 passengers. Thus, we come to the total number of 71250 passengers in scheduled air transport that are potential customers of the Mostar Airport.

Also the $20 \%$ of the passengers from the religious tourism segment that visit Međugorje by scheduled lines (48 000) should be taken into account. With that number, the maximum potential in the segment of scheduled air transport can be estimated at 119250 passengers (Fig. 4).

Annual and peak traffic forecasts are performed for the highest expected traffic at the location, for the planned year [7].

Bearing in mind the necessity of the forecasting of the future traffic, Tab. 1 presents a ten-year traffic forecast for the Mostar Airport.
Taking into consideration the large investments that are needed to eliminate limiting factors and the time needed for the preparation of the projects and their implementation, mid-term traffic forecast at this time represents a realistic projection.

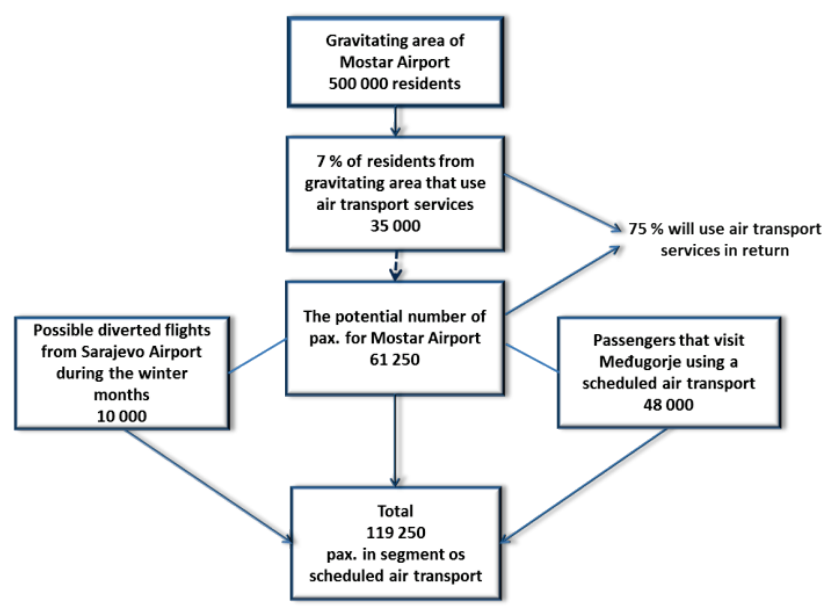

Figure 4 Estimation model of maximum potential passenger arrivals for the Mostar Airport in the segment of scheduled air transport [5]

\section{Elements of the Mostar Airport strategic development model}

There are a number of limiting factors that should be considered for removing before the Mostar Airport could realize its projected traffic potential. In the first place, there is the requirement for the harmonization of airport infrastructure to international standards. Also there is a lack of aircraft parking positions (only two parking positions for reference aircraft type A320) and a problem with the passenger terminal capacity with only two checkin counters; a gate for departure and a gate for arrival. There are a number of other issues that should be addressed in order to give the projected results.

Table 1 Passenger traffic forecast for the Mostar Airport from 2014 to 2024 [5]

\begin{tabular}{|c|c|c|c|c|c|c|}
\hline Year & $\begin{array}{c}\text { Optimistic } \\
\text { forecast }\end{array}$ & $\begin{array}{c}\text { The planned increase } \\
\text { in traffic (\%) }\end{array}$ & Realistic forecast & $\begin{array}{c}\text { The planned increase } \\
\text { in traffic (\%) }\end{array}$ & $\begin{array}{c}\text { Pessimistic } \\
\text { forecast }\end{array}$ & $\begin{array}{c}\text { The planned increase } \\
\text { in traffic (\%) }\end{array}$ \\
\hline 2010 & 17850 & Achieved & - & Achieved & - & Achieved \\
\hline 2011 & 36812 & Achieved & - & Achieved & - & Achieved \\
\hline 2012 & 78205 & Achieved & - & Achieved & - & Achieved \\
\hline 2013 & 68939 & Achieved & - & Achieved & - & Achieved \\
\hline 2014 & 67974 & Achieved & - & Achieved & - & Achieved \\
\hline 2015 & 81569 & $20 \%$ & 78170 & $15 \%$ & 74771 & $10 \%$ \\
\hline 2016 & 89726 & $10 \%$ & 85987 & $10 \%$ & 80005 & $7 \%$ \\
\hline 2017 & 98698 & $10 \%$ & 92866 & $8 \%$ & 85606 & $7 \%$ \\
\hline 2018 & 106594 & $8 \%$ & 100295 & $8 \%$ & 89030 & $4 \%$ \\
\hline 2019 & 115122 & $8 \%$ & 106313 & $6 \%$ & 92591 & $4 \%$ \\
\hline 2020 & 124331 & $8 \%$ & 112692 & $6 \%$ & 96295 & $4 \%$ \\
\hline 2021 & 133035 & $7 \%$ & 117200 & $4 \%$ & 99184 & $3 \%$ \\
\hline 2022 & 141017 & $6 \%$ & 121888 & $4 \%$ & 102159 & $3 \%$ \\
\hline 2023 & 149478 & $6 \%$ & 125544 & $3 \%$ & 104202 & $2 \%$ \\
\hline 2024 & 156952 & $5 \%$ & 129310 & $3 \%$ & 106286 & \\
\hline
\end{tabular}

\subsection{Strategic planning of airports}

When performing strategic planning the following activities should be included:

- review of the current and future challenges that the airport is, or may be, facing;
- development of a vision concerning the airport's future layout and definition of project management plan activities that should be performed in order to achieve the airport's vision. 
Strategic planning for airports should provide answers to the following questions:

- How to adapt to changing conditions?

- How to allocate resources?

- How to compete in every single area in which company appears in terms of satisfying the needs of customers?

- How to position the company and the product compared to the competition and avoid problems?

- How to determine the actions and approaches that strengthen each functional and operational part of the company?

There are three groups of analyses that ensure identification of factors influencing the choice of strategy:

- Analysis of general or social environment;

- Analysis of the business environment or task environment;

- Analysis of the internal environment or internal analysis.

These analyses consist of determining the position of the company in its environment and the choice of optimal strategy to operate successfully in that environment.

Usually conducted method is PEST analysis which determines opportunities or threats from [8]:

- Political and legal environment (P),

- Economic environment (E),

- Socio-cultural environment (S),

- Technological environment (T).

Determination of the airport strategic development model starts from the fact that today it is not possible to separately analyse only the infrastructure development, but it is necessary to look at the airport development as businesses subjects that are open to the market and should be observed in the planning of the airport business strategy.

Classic priorities are now replaced by newly arisen priorities: customer priority, profit, share value, innovations, business models, leadership [9].

During the strategic planning process key questions need to be answered. The following questions are described in Fig. 5.
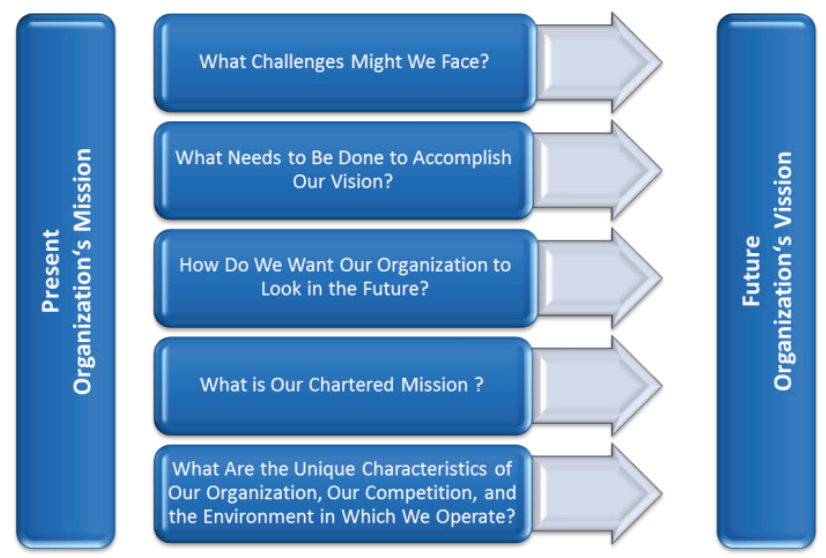

Figure 5 Key questions in the airport strategic planning process [10]

The Mostar Airport, along with its owners, the City of Mostar, the Zagreb Airport and other stakeholders, should examine its current situation, understand where it stands and specify the path which it wants to take in the future. That primarily implies a statement of mission and vision of the organization.

In the case of the Mostar Airport, which should be transformed from the traditional into a commercial system, the focus should be put on a very attractive land surrounding the airport, bearing in mind the possible need to extend the runway to the north.

Airport management should, in cooperation with local authorities, ensure that this land is firstly protected from any kind of construction, and then determine the ownership of land and gradually go for redemption. On the other hand, apart from operational areas and aprons, the complex of the Mostar Airport covers more than 70 hectares of construction land with a fully developed utility infrastructure (requires restoration) and buildings and former military objects. There are also aircraft hangars, storage tanks and systems for the distribution of aviation fuel, etc. Therefore, the management of the Mostar Airport should, in strategic planning phase, certainly consider the possibilities of efficient land usage that is currently available and develop a model to increase revenues on the account of space issues and facilities in the complex.

When developing airport management strategic plans, it is necessary to obtain a greater number of options from a diverse group of stakeholders, which might have diverse role in the process of strategic planning. This stakeholder diversity is illustrated in Fig. 6.

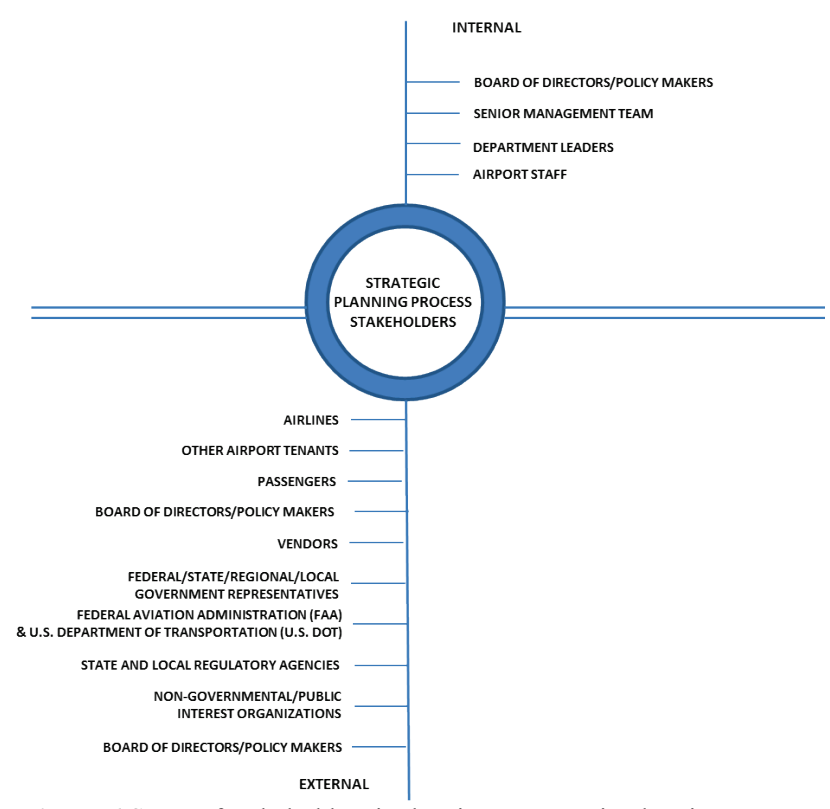

Figure 6 Some of stakeholders in the airport strategic planning process [10]

The Mostar Airport should in the phase of the strategic planning also consult a large number of parties who have a direct or indirect impact on their activities. In the first place there are the owners, and many governmental and non-governmental institutions and ministries. They should consult the tourist associations, tourist organizations and tour operators who operate in the area of Bosnia and Herzegovina. They should also consult air carriers that operate at the airport or just plan to start 
an operation, and many other "minor" subjects which can help with their contribution in gathering information and qualitative assessment of the existing situation and better perspective on the future needs of the community.

\subsection{The strategic planning process of airport}

Airport strategic planning starts with setting the goals. Then an inventory is taken of the quantity and quality of existing infrastructure and the way it is being used. This will include the use of performance indicators tailored to determine those aspects where the system is falling short of its goals [11].

The airport planning activities represent a starting point when performing strategic planning. Second step includes assessment of the historical development of the organization, mission evaluation, vision and core values, internal and external environment in which the airport operates and discusses the strategic issues and identifies strategies for achieving comparative advantage over the competition. In the third step it defines the short-and longterm objectives and action plans to be implemented in order to achieve the desired vision of the airport. Framework of the strategic planning process for the airport is presented in Fig. 7.

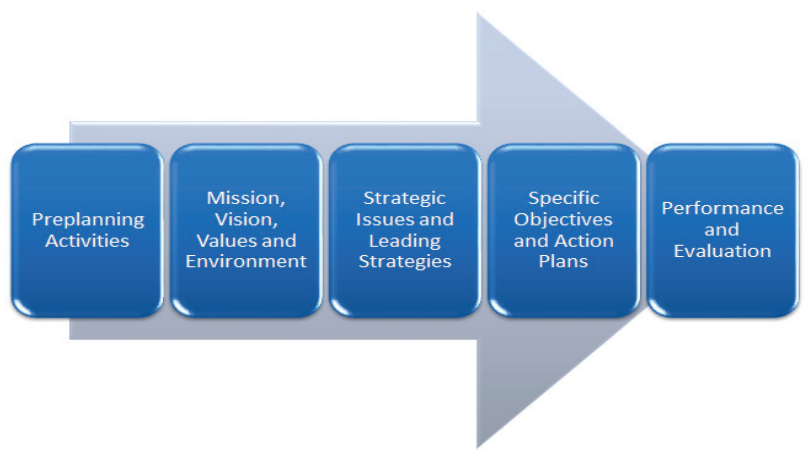

Figure 7 The airport strategic planning process framework [10]

Flow chart of the four main phases of the airport strategic planning process is presented in Fig. 8.

Depending on the size of the organization, its complexity, time and effort invested in the strategic planning process and the number of participants in the process, the amount of data collected, reviewed and analysed as well as the outcome of the entire process vary.

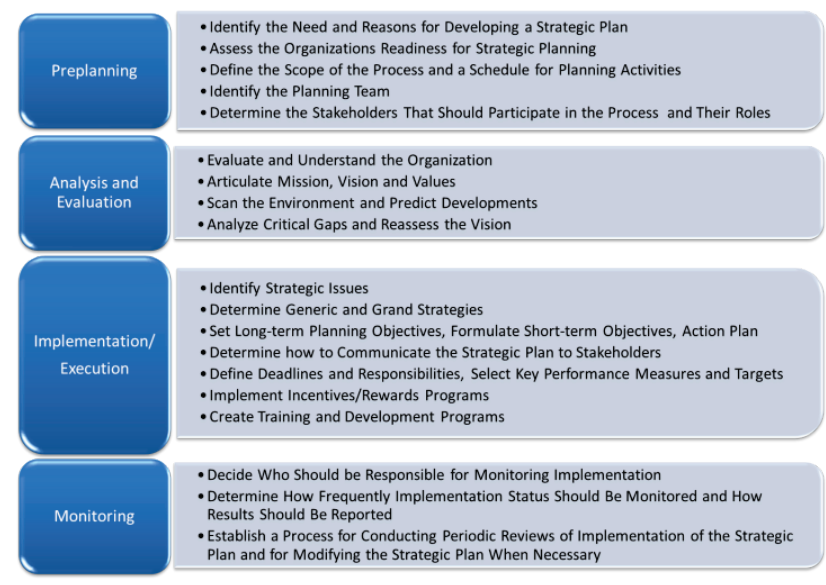

Figure 8 Four phases of the airport strategic planning process [10]
Prerequisites and the reasons for the development of a strategic plan for the Mostar Airport arise from the fact that at the national level there is a no clear strategy for the development of airports and there is not a single document at the strategic level that is applicable to the Mostar Airport. Therefore, for the purpose of positioning the Mostar Airport in the European network of regional airports, and in order to ensure the necessary development of the airport area, it is necessary to produce a strategic plan.

In the second phase, the Mostar Airport in the developing phase of the strategic plan, should define a mission and vision statement. Analysis of the airport critical deficiencies may cause the change of airport's vision, in order to conform with internal strengths and weaknesses. Analysis of the organization in the first place indicates a lack of motivation of employees, lack of professional staff and various engineering profiles, high average age and problems in a number of staff for two shift work organization in order to compete opening hours of the Sarajevo Airport.

Analysis of the airport environment and predicting the airport's future development is necessary to recognize the airport's strengths and weaknesses. Analysis would serve as a basis for positioning the Mostar Airport in the European network of regional airports in order to determine the key guidelines for the development of a strategic plan. Therefore, it is necessary to predict different types of airplanes that will and could in the future operate at the Mostar Airport. Also, it is necessary to analyse current and predict future restrictions for larger types of aircraft, in order to be able to react on time through strategic plan, in order that restrictions do not become the reason for stagnation of traffic at the airport.

The third phase of strategic planning is generally the most demanding. At this stage, the Mostar Airport must define strategic issues that should be indicated in the strategic plan. Strategic issues are based on the analysis of the results from the second phase of the strategic planning process. It is necessary to define a general approach and the generic strategic model on which basis strategic plan adapts to the major strategic issues of the Mostar Airport. During this process the sub-processes are determined that should develop specification plans.

An important part of the strategic planning process presents communication with the stakeholders in the process, as well as the presentation of the strategic plan results to target potential companies. In this sense, the Mostar Airport could develop special communications plan that may (or may not) be part of the strategic plan. Ultimately, implementation of the strategic plan is largely dependent on the communication of strategic objectives to all stakeholders. In the third phase of the strategic planning process the main objectives and performance indicators must be determined in order to be able to evaluate, analyse and improve the realization of the process.

For the purpose of obtaining maximum results from the various entities involved in the process of strategic planning, the Mostar Airport shall develop a program of incentives and rewards, especially for the most active participants in the process. Incentives and rewards do not necessarily have to be expressed $n$ financial nature. 
Therefore, it is necessary to gather all participants to recognize their interests and needs, and in accordance with the results of the survey develop the program.

In order to successfully implement the strategic plan it is necessary to create special programs for training and development for each employee that could contribute to the successful implementation of the strategic plan.

Phase control and supervision, as the last stage, should be carried throughout the strategic planning process. At this stage, the key performance indicators identified during the third phase (implementation and enforcement) are controlled and monitored in order to assess the time efficiency of the strategic plan and need for additional adjustments.

The Mostar Airport, together with the main entities responsible for development of strategic plan and control of the process, shall decide who is responsible for supervision and implementation of the strategic plan. It can be a private or legal entity as well as it is the case of the Mostar Airport. It the case of the Mostar Airport the best solution would be a person employed at the airport, which actively participates in the process of development of strategic plan. By doing that, the Mostar Airport would ensure that the person responsible for oversight of realization is competent and well informed about all main sub-processes that should be performed.

Given the fact that the fulfilment of a strategic plan is a long-term process, and the fulfilment is significant for all stakeholders, besides monitoring of the implementation plan, the Mostar Airport shall develop forms and elements that will be regularly communicated to management board. The realization of the strategic plan consists of a large number of activities, defined deadlines and a great number of participants. Therefore the report should be short, unambiguous, with insight into all activities and level of implementation for each of the individual activities.

The strategic planning process usually results in one key document, the strategic plan, but it can be further improved by creating a communication plan and the plan of supervision and control. Given its size and the volume of traffic for the Mostar Airport it is not necessary to develop a communication plan and the plan of supervision and control. It is sufficient that the individual elements of these documents are included in the strategic plan.

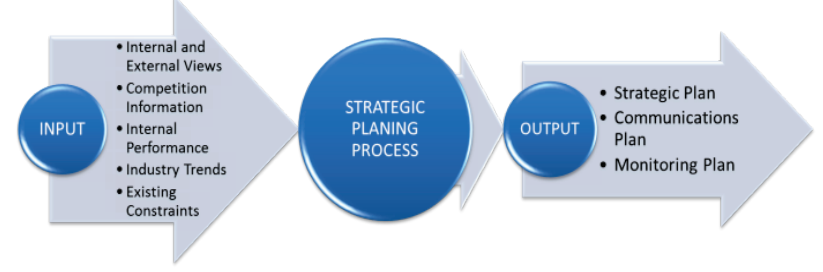

Figure 9 Inputs and outputs of the strategic planning process [10]

Fig. 9 shows the input and output parameters of the airport strategic plan. The strategic plan, a communication plan and a plan of supervision and control are the main outputs of the process.

Airport market coverage is usually determined as a narrower coverage, to 1 hour drive from the airport and wider coverage usually 2 hours' drive from the airport.
Considering that, the analysed geographic area is relatively small and is covered with several airports. The authors in this paper separated those that are within 200 kilometres from Mostar and those are the airports in Sarajevo, Split and Dubrovnik (Fig. 10). In the wider area there are four airports: Tuzla, Banja Luka, Zadar and Tivat.

Although all three airports in narrower coverage from traffic aspects are incomparable with the Mostar Airport, the fact is that all of these airports deprive a significant number of passengers from the Mostar Airport.

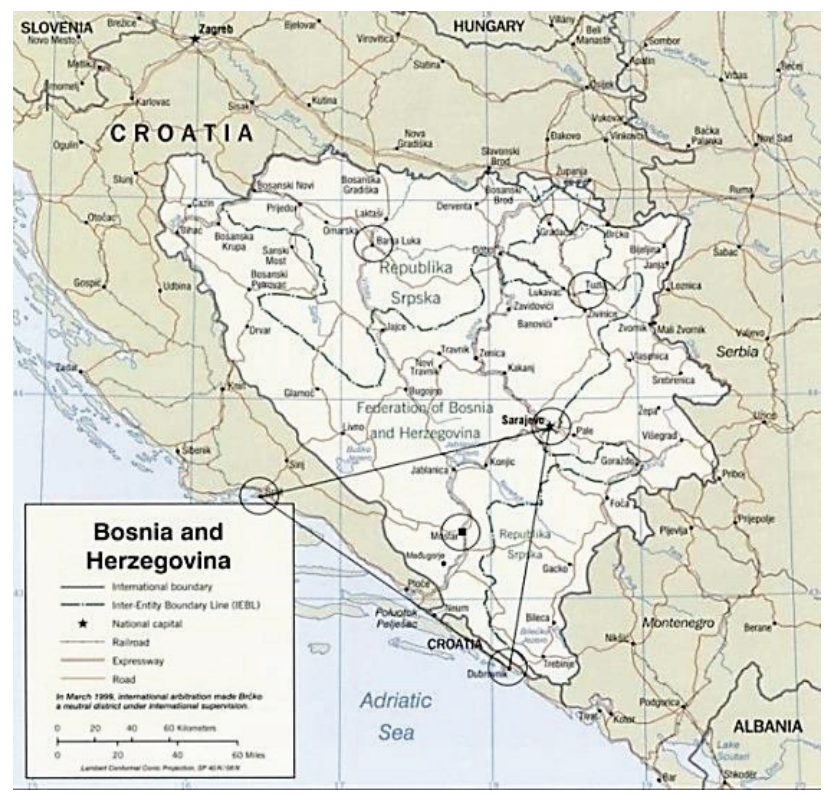

Figure 10 Position of the Mostar Airport compared to the competing airports Sarajevo, Split and Dubrovnik

Source: Made by authors

Looking from the aspect of infrastructure and compliance with international regulations, the data that is available in the Aeronautical Information Publication (AIP) points to the fact that none of these airports is in line with international standards and recommendations. Airport terminals due to the volume of traffic and peak hour loads cannot be the object of comparison. Service prices observed on analysed airports are higher than tariffs at the Mostar Airport. Prices of commercial facilities and lease are also significantly higher.

Working hours of competing airports are from 6 to $22 \div 23$, and working hours of the Mostar Airport, although officially published from 6 to 15, are actually flexible and aircrafts are accepted and deployed at any time of day or night. It is important to emphasize that in the Mostar Airport, there are no restrictions on aircraft noise.

There are a number of other elements that must be taken into account in order to analyse the environment regarding the competing airports. Analysis of this kind is certainly not an independent document, but only a part of the airport's planning documentation of higher order such as master plan or strategic plan of the airport. In doing so, the analysed results determine the short-term and longterm guidelines for further business steps at multiple levels, such as infrastructure guidelines, economic and marketing guidelines, pricing policy, customer service, etc. 
Short-term development plan for the Mostar Airport is mostly based on the alignment of infrastructure with ICAO standards. Considering that the Mostar Airport during the war in Bosnia and Herzegovina suffered significant damage, and airport infrastructure was primarily built for the military purposes, it is necessary to devise a plan for harmonizing infrastructure with international standards and the requirements for aircraft that are commonly used at the airport.

Short-term development plan for the Mostar Airport was made in 2005, to be performed by 2010. Eight projects were scheduled, and only one was fully realized construction of technical centre.

This situation points to the fact that unrealistic goals were set that have not been sufficiently coordinated with the owner of the airport and for financial reasons have not yet been realized. Therefore, it is necessary to prepare a revision plan and consider all the circumstances that may have an impact on the realization of certain objectives and accordingly redefine the limits within the listed projects that will be realized in the short-term plan.

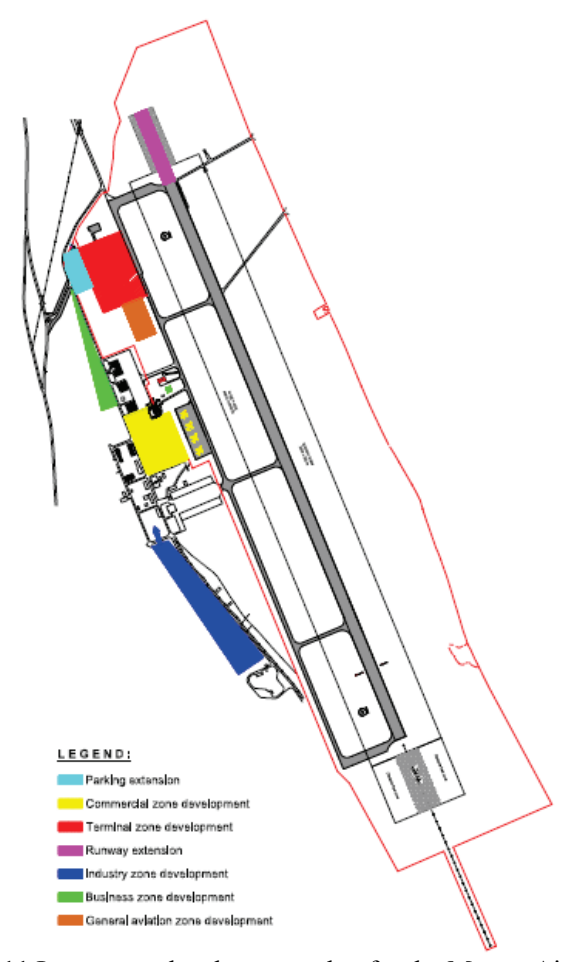

Figure 11 Long-term development plan for the Mostar Airport [5]

Long-term development plan is in full compliance with the short-term plan, and it seems as its logical extension (Fig. 11). It is important to emphasize that for the development of certain areas there are still no concrete plans.

Therefore, for each zone, which is the subject of a long-term development plan, it is necessary to develop special projects in order to make it possible to efficiently use as most as possible the area at and around the airport, with thematically and logically related entities, in order to improve the quality of services at the Mostar Airport.

Long-term development plan was prepared with an imaginary deadline term for implementation by 2020 . However, so far nothing has been performed in terms of resolving property issues and development projects, so it is not realistic to expect that the long-term development plan will be implemented within the planned period.

The strategic plan sets the foundation for the planning and defines the guidelines that the airport should follow in order to achieve their vision (Fig. 12).

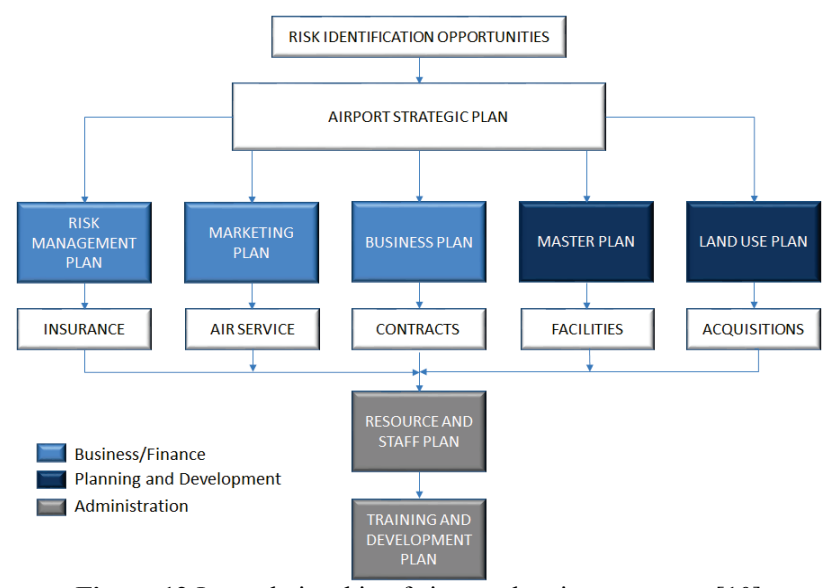

Figure 12 Interrelationship of airport planning processes [10]

A key component of a strategic planning, such as a review of the external environment, may pose threat or opportunities to the organization. Among most important issues of the strategic planning process, the Mostar Airport should include a risk management plan and a marketing plan.

The concept of risk management has three essential elements: perception of whether some adverse event could really occur, the probability that will actually occur, and the consequences of adverse events that could occur. The risk, therefore, is the result of synergy interaction of these three elements.

The risk management system should be viewed as a subsystem of the management system, which along with others makes a complex interaction [12].

It is necessary to identify internal and external risks that can jeopardize the process of strategic planning and implementation of a strategic plan for the Mostar Airport.

Once the risks are identified, it is necessary to determine the probability that some of the identified risks could cause delays or issues in the process of drafting or implementation of the strategic plan. When identified and assessing the risk probability, the Mostar Airport must make an assessment of the impact of risk on business processes and predict the introduction of such measures that will reduce or completely eliminate the risk probability that affects the process of strategic planning and implementation of the strategic plan.

In order to successfully meet the needs of the airlines, passengers and other stakeholders in the air transport, airport marketing department should take part in activities such as quality and preferences research of all types of customers, communication and satisfaction surveys.

The introduction of a low-cost carrier scheduled flights would allow the use of more and more pronounced trend of individual booking, which is based on scheduled traffic and on line bookings. This would compensate for the lack of interest of the national air carrier BH Airlines to establish a year-round scheduled airline through Mostar.

The development of tourism in the HerzegovinaNeretva Canton (county in B\&H with highest volume of tourist traffic) has very good prerequisites for further 
development of the Mostar Airport. Nevertheless, it seems that sudden rise in the Mostar Airport passenger number in the last three to four years is not a result of strengthening of Herzegovina as an air travel destination, since only $1,5 \%(15000)$ of the total number of passenger arrivals belong to those who have organized transfer in hotels in Međugorje and Mostar.

Since the Mostar Airport is located in the country that carries out radical structural reform, and until now it was always in the public property, the first step is the gradual transformation from the public property into the commercial company. The privatization of the Mostar Airport is still not a viable option, neither its management takeover by the global companies. Great opportunities for further development, through the transformation into a commercial company, lie in the efficient management of the airport area. Given the very low traffic, revenues from non-aeronautical services at the Mostar Airport are minimal. Information about the cost of various passenger categories is not known to the airport because such data is not tracked, while the share of the labour costs in total airport revenues is more than $90 \%$. The rest of the revenues are allocated to the maintenance of current facilities and procurement of the necessary equipment. The reason for such a high proportion of labour costs lays in the extremely low traffic, unfavourable contracts and under the use of other facilities, infrastructure and airport facilities that could be commercialized.

\section{Conclusion and discussion}

The Mostar Airport is the key stakeholder of air traffic in the Herzegovina region. Due to its geographical position, it is crucial for the development of air transport and tourism in the region. The ownership structure of the airport complicates its future development. The continuous air traffic growth in the region, speaks about major transportation resources that can be linked primarily to the tourist offer of the regions Herzegovina and Dalmatia in neighbouring Croatia.

Strategic development model focuses on increasing the market share, increase of quality of service, capacity increase and efficiency increase, with the use of an integrated and well balanced approach to all stakeholders who have a direct or indirect benefit from the increase of air traffic in the region.

The Mostar Airport has no development plans that are common in aviation environment - master plan and strategic plan. The first priority for the Mostar Airport management board in the future should present the development of two abovementioned plans. Strategic plan is intended for further development and implementation by the Mostar Airport but with slight adjustments it can be a respectable guidance for other small and regional airports on how to develop their own strategic plans.

Currently, there are many infrastructural facilities which could be converted into business objects with small investments. Through the strategic plan and its constituent elements that relate to long-term airport development plan, the Mostar Airport should take the advantage over large areas around the airport with complete infrastructure suitable for development of various business activities. One of the final results could be development of various airport business zones that could expand non-aviation activities and increase revenues.
Even though there is an expectation of significant traffic growth (between 8 to $10 \%$ of annual traffic growth in average until 2025) as presented in the paper, the figures presented are challenging and it may be necessary to intervene on all administrative levels, such as political and not only operational to achieve these numbers. The accession of B\&H to the EU and the opening of national air transport market present significant opportunity for all the carriers operating in the EU and residents of $\mathrm{B} \& \mathrm{H}$.

\section{References}

[1] Kwakkel, J. H.; Walker, W. E.; Marchau, V. A. W. J. Adaptive Airport Strategic Planning. // EJTIR European Journal of Transport and Infrastructure Research. 10, 3(2010), pp. 249-273.

[2] Badanik, B.; Laplace, I.; Lenoir, N.; Malavolti, E.; Tomova, A.; Kazda, A. Future Strategies for Airports. // $27^{\text {th }}$ International Congress of the Aeronautical Sciences, ICAS 2010, Nice, France, 19 - 24 September 2010.

[3] Graham, A. Managing Airports - An International Perspective, 3rd edition, p.p. 275, Elsevier, 2008.

[4] ATAG - Air Transport Action Group, Aviation Benefits Beyond Borders. 2014. URL: http://www.atag.org/ourpublications/latest.html (06.05.2015).

[5] Galić, D. Strateški model razvoja zračne luke Mostar, Magistarski znanstveni rad, Sveučilište u Zagreb, Fakultet prometnih znanosti, 2012.

[6] Horonjeff, R.; McKelvey, F.; Sproule, W.; Young, S. Planning and Design of Airports, Fifth edition, McGraw Hill, 2013.

[7] Pavlin, S. Aerodromi II, Sveučilište u Zagrebu, Fakultet prometnih znanosti, Zagreb, 2011.

[8] Čičin-Šain, D. Strateško planiranje, Predavanje iz osnova menadžmenta, Zagreb, 2005.

[9] Novak, L. Model razvoja Zračne luke Split, Magistarski znanstveni rad, Fakultet prometnih znanosti, 2006.

[10] Transportation Research Board of the National Academies, ACRP report, Strategic Planning in the Airport Industry, Sponsored by Federal Aviation Administration, Washington D. C., 2009. URL: http:/www.trb.org/ Publications/Public/PubsACRPProjectReportsAll.aspx (06.11.2013).

[11] Caves, R. E.; Gosling, D. E. StrategicAirportPlanning, Pergamon, 1999.

[12] Drljača, M.; Bešker, M. Održivi uspjeh i upravljanje rizicima poslovanja. // XIV. savjetovanje SQM 2010, Centar za kvalitet Crne Gore i časopis Kvalitet, br. 7-8, Poslovna politika / Beograd, Tivat, 2010, pp. 33-39.

\section{Authors' addresses}

Asst. Prof. Andrija Vidović, Ph. D.

Faculty of Transport and Traffic Sciences, University of Zagreb, Vukelićeva 4, 10000 Zagreb, Croatia Phone number: +385-1-245-7724

E-mail: avidovic@fpz.hr

Asst. Prof. Tomislav Mihetec, Ph. D.

Croatian Civil Aviation Agency,

Vukovarska 284, 10000 Zagreb, Croatia

Phone number: +385-1-236-9377

E-mail: tomislav.mihetec@ccaa.hr

Daniel Galić, M. Sc.

Croatian Civil Aviation Agency,

Vukovarska 284, 10000 Zagreb, Croatia

Phone number: +385-1-236-9377

E-mail: daniel.galic@ccaa.hr 